\title{
ASSESSMENT OF COMMON BEAN (PHASEOLUS VULGARIS L.) SEED QUALITY PRODUCED UNDER DIFFERENT CROPPING SYSTEMS BY SMALLHOLDER FARMERS IN EASTERN ETHIOPIA
}

Kedir Oshone $^{1}$, Setegn Gebeyehu ${ }^{2 *}$, Kindie Tesfaye ${ }^{3}$

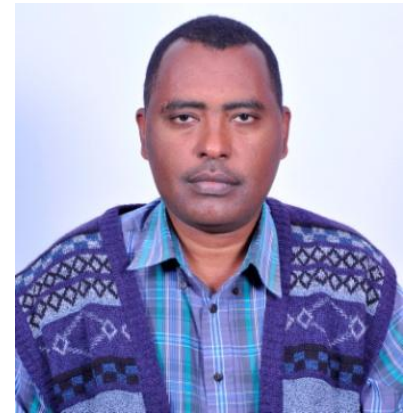

Setegn Gebeyehu

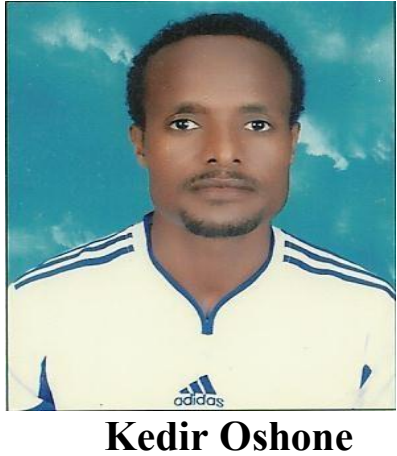

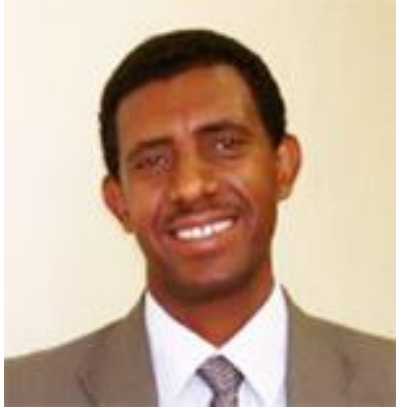

Kindie Tesfaye

*Corresponding author's email: setegn.gebeyehu@gmail.com

${ }^{1}$ Haramaya University, School of Plant Sciences, P. O. Box 138, Dire Dawa, Ethiopia 2International Institute of Tropical Agriculture (IITA), 32 Poplar Road, Avondale, Lusaka, Zambia.

${ }^{3}$ International Maize and Wheat Improvement Center (CIMMYT), P.O.Box 5689, Addis Ababa, Ethiopia. 


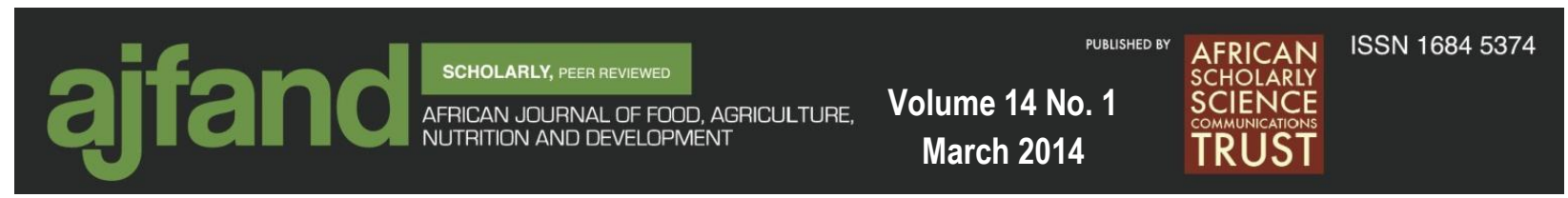

\begin{abstract}
One of the major causes of low yield of common bean in Ethiopia is the shortage and/or inaccessibility of high quality seed. In the Hararghe highlands of eastern Ethiopia, farmers often use common bean seeds produced both under sole crop and intercrop systems. This study was carried out to investigate the physical, physiological and health qualities of common bean seed produced under sole crop and intercrop systems by smallholder farmers of three districts of West Hararghe zone, Eastern Ethiopia. Samples from seed retained for 2011 main cropping season planting were collected from 100 households and tested using standard laboratory procedures. Results indicated that seeds obtained from sole crop were different from those obtained from intercrop system in physical purity and percentage of pathogen infected seeds whereas the physiological quality related characteristics were similar between the two cropping systems. With a mean pure seed proportion of above $98 \%$, all seed samples obtained from sole and intercrop cropping systems met the national seed standard for common bean seed (95\%). About 20 and 50\% seed samples obtained from intercrop and sole crop, respectively, had seed moisture content below the minimum national standard for common bean seed (12\%). Standard germination of seeds of both cropping systems exhibited a wide range of variation with a mean of 75 and $84 \%$ for sole crop and intercrop originated seeds, respectively. Common bacterial blight (Xanthomonas campestris pv. phaseoli) and Aspergillus flavus were the most common bacterial and fungal diseases associated with the seed samples. Higher percentage of CBB infection was found for sole seeds relative to those obtained from intercrops. It is concluded that in areas where agricultural land is limited, farmers can produce and use common bean seed of acceptable quality produced under sole and intercropping systems provided that appropriate production and post-harvest management practices are followed.
\end{abstract}

Key words: Common bean, intercropping, seed quality 


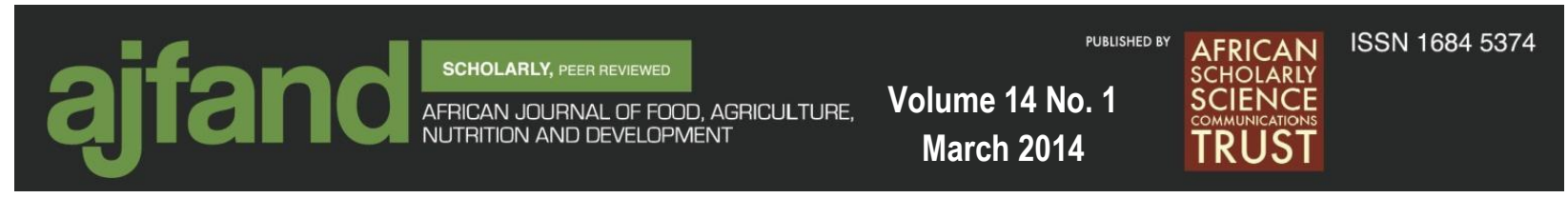

\section{INTRODUCTION}

Common bean is one of the major food and cash crops in Ethiopia and it has considerable national economic significance. It is often grown as cash crop by smallscale farmers and used as a major food legume in many parts of the country where it is consumed in different types of traditional dishes [1]. The area devoted to common bean production in Ethiopia is 359235 ha with a total production of $0.41 \mathrm{M}$ tons and average yield of $1.2 \mathrm{t} / \mathrm{ha}$ [2]. It is mainly grown in eastern, southern, south western, and the Rift valley areas of Ethiopia [3, 4]. In the semi-arid to sub-humid highlands of Hararghe, common bean is grown mostly intercropped with sorghum, chat and maize and seldom as a sole crop by subsistence farmers [5]. In this region, $91 \%$ of common bean and 64\% of maize are grown in intercropping systems [6]. Common bean is normally grown twice a year in the area. The first production is during the short rainy season (April to June) and second is during the long rain season (July to October) [7].

Several studies have demonstrated the increased land productivity advantage due to maize-common bean intercropping in the Hararghe highlands owing to efficient use of resources, minimized soil erosion and increased soil fertility [8, 9]. As in other bean growing regions of Africa, the majority of farmers get their seeds mainly from informal channels which include farm saved seeds, seed exchanges among farmers and/or local grain/seed market. These channels contribute to more than $95 \%$ of common bean seed supply in Hararghe highlands of Ethiopia [10]. A distinct purpose of common bean production (whether for grain or seed) by smallholder farmers is virtually lacking and products from preceding one or two seasons are usually used as planting material for succeeding seasons regardless of the cropping system used to produce them [10]. Lack of adequate and quality seed supply through the formal system on one hand and the limited technical support to promote informal seed systems on the other, have hindered farmers' access to improved seed in the past. Considering that most bean production takes place in an intercrop system with maize and sorghum, understanding quality of seed produced and participatory planning, and testing of practices that help produce seeds of acceptable quality under different intercropping system would be a sound strategy for the assurance of the supply of high quality seeds for the area.

Seed physical and physiological quality can be affected by genetic factors as well as the ecological conditions and pre- and post-harvest management practices followed by farmers [11]. Management practices carried out at different crop growth stages of the component crops in an intercropping system may affect not only yield but also quality of seeds produced under adverse competition for growth resources. Wide fluctuation in the germination and emergence of legume seeds faced in the field is often caused by the use of poor quality seeds [12], poor storage conditions [13], increased incidence of seed-borne fungal infection [14] and sowing and harvesting when environmental conditions are unfavorable [15].

Studies have shown that seeds of legumes (soybean, peanut and mung bean) produced in an intercropping system with maize and sugarcane had low germination capacity 
and vigor and hence did not qualify for planting material $[16,17]$. On the contrary, other studies have pointed out that bean seed quality parameters such as seedling growth rate, shoot length and seed sizes were unaffected when produced under maizebean intercropping systems [18]. The hypothesis to be tested in this experiment is whether seeds produced under intercropping are of worse quality compared to seeds produced under sole crop system, assuming farmers use mixed varieties regardless of the cropping system they practice. Unlike sole cropping, intercropping changes the dynamics of crop disease and pests and thereby affects seed health. Seed health primarily refers to the presence or absence of disease causing organisms, such as fungi, bacteria and viruses which have direct bearing on crop yield [19]. Therefore, the objective of this study was to assess the physical, physiological and health qualities of common bean seed produced under sole and intercrop cropping systems of smallholder farmers in the Hararghe highlands of eastern Ethiopia.

\section{MATERIALS AND METHODS}

\section{Description of the study area}

The seed samples were collected from three districts (Tulo, Dobba and Gemachis) of West Hararghe Zone, Oromia Regional State of Ethiopia a couple of weeks before common bean planting was started during the main cropping season of 2011 (Fig. 1). The three districts were selected because of their importance in common bean production, which attracted a number of research and development organizations to intervene with different common bean seed system activities over the past couple of years. The altitude of the three districts ranges from 1400 to over 2800 meters above sea level. The topography consists of complex features of landscape comprising flat to gentle slope, gorges, hilly and mountainous areas. The area is characterized by a bimodal rain fall pattern with annual rainfall range of $650-1300 \mathrm{~mm}$ with the maximum rainfall received in the months of June to August. There are two cropping seasons, short/belg (March to May) and main/meher (July to October). The mean annual minimum temperature is $16{ }^{\circ} \mathrm{C}$ while the mean annual maximum temperature is $28{ }^{\circ} \mathrm{C}$ with an average temperature of $22{ }^{\circ} \mathrm{C}$. Common bean is among major food and cash crops grown in the area. Mixed intercropping with sorghum and maize is the dominant system of common bean production in the area with 88,96 and $95 \%$ of total area allocated to the crop in Doba, Tullo and Gemechis districts, takes place under this system [10]. 


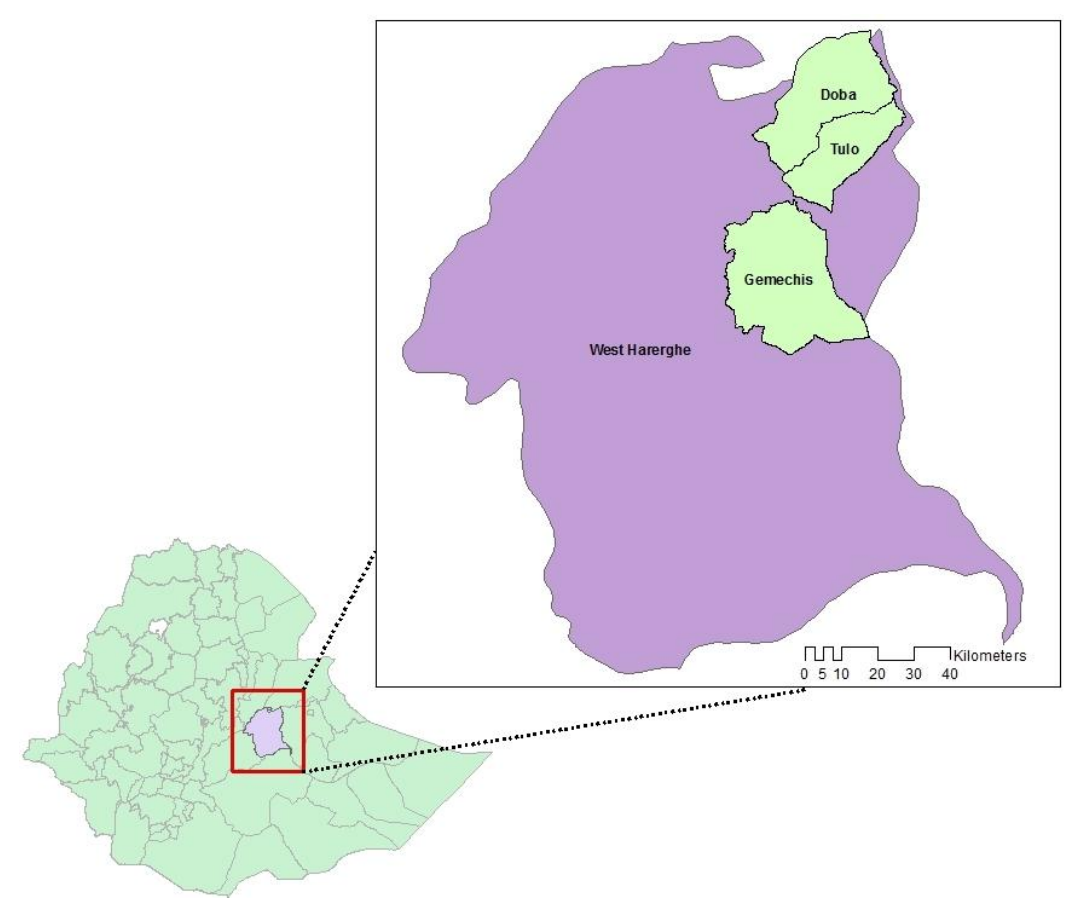

\section{Figure 1: Location of study districts in the West Hararghe Zone, eastern Ethiopia.}

\section{Seed sample collection}

About one kilogram seed that was intended for planting during the main cropping season of 2011 was collected from one hundred randomly selected farmers (30 in Tulo, 40 in Dobba, and 30 in Gemechis districts). Whereas 76 samples were collected from farmers who produced the seed under intercropping, the remaining 24 were taken from those who produced the crop (seed) under sole crop system. The seed samples collected were immediately taken to laboratory for seed quality analysis.

\section{Seed quality test}

Seed collected from farmers was divided for laboratory tests such as physical purity, physiological quality, and seed health test. All tests were performed at Melkassa Agricultural Research Center and Haramaya University seed testing laboratories following the International Seed Testing Agency procedures [20]. For seed quality tests, treatments (seed samples collected from 100 households) were laid out in Completely Randomized Design with four replications.

Physical purity \& physiological quality test: The seeds were separated based on their sources, varieties and cropping system, and a kilo gram of each working sample of seed was tested in the laboratory for physical purity and physiological quality. As specified by ISTA, the minimum sample of common bean seed submitted to the seed testing laboratory for analysis was $1000 \mathrm{~g}$ while the working sample was $700 \mathrm{~g}$. 


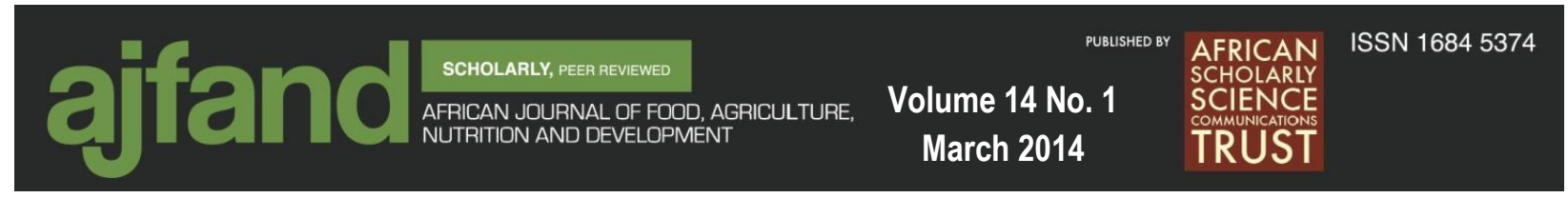

Physical purity test: Each working sample was divided into two $350 \mathrm{~g}$ portions for physical purity analysis. The components were separated into pure seed, inert matter, and weed seed, and seed of other crops, and each component was weighed using analytical balance. Finally, the percentage composition of the seed lot was calculated based on the weight of each component [21].

Moisture content determination: For seed moisture content determination, high constant temperature oven dry method $\left(130-133{ }^{\circ} \mathrm{C}\right.$ for about one hour) was used. The moisture content as a percentage by weight was calculated to one decimal place following the standard formula [22].

Physiological quality test: For standard germination (SG) test, four hundred seeds from pure seed components of each sample were divided into four replicates of one hundred (100) seeds each. Seeds were planted using sand substratum in the sand. After sown seed containers were incubated at temperature of $25{ }^{\circ} \mathrm{C}$, first and final counts were made 5 and 9 days after planting, respectively as specified by ISTA [19]. At the end of the SG test, germinated seeds were divided into normal and abnormal seedlings while ungerminated ones were grouped into hard and dead seeds and the percentage of each component was calculated following ISTA's procedure [21].

The seedling shoot and root lengths were assessed after the final count was made in the standard germination tests. Five normal seedlings were randomly taken from each replication. The shoot length was measured from the point of attachment to the seed up to the tip of the seedling, while the root length was measured from the point of attachment to the seed to the tip of the root. The average shoot and root length were computed by dividing the total shoot and root lengths by the total number of normal seedlings measured [23].

Seedling dry weight was the other method used to test seed vigor in the study. The seedling dry weight was measured after the final count in the standard germination test. Five seedlings were randomly taken from each replication, detached from the seed, placed in envelops and then dried in an oven at $80{ }^{\circ} \mathrm{C}$ for 24 hours. The dried seedlings were weighed to the nearest gram and the average seedling dry weight was calculated. The seed exhibiting maximum seedling dry weight is considered as vigorous [24]. Vigor index I (VIG I) was calculated by multiplying the normal germination (\%) with the sum of average shoot and root lengths after nine days of germination and Vigor index II (VIG II) was calculated by multiplying the normal germination (\%) with mean seedling dry weight.

Two hundred pure seeds were counted and taken from each seed source and then divided into four replicates having 50 seeds each for the determination of speed of germination. The seeds were sown in sand substrata and left in seed germinator at 25 ${ }^{\circ} \mathrm{C}$ for 9 days. The seeds were then assessed for the presence of normal seedlings: first count was made on the fifth day and final count was done on the ninth day after incubation. Germination was assessed as the percentage of seeds producing normal seedlings as defined by ISTA [20]. The normal seedlings were counted and removed 
each day, and the speed of germination was calculated by dividing the number of normal seedlings removed each day by the number of days during which they were removed [24].

Seed health test: Seed samples were studied for the presence of seed-borne pathogens associated with common bean seed produced under different cropping systems. Identification of different seed-borne pathogens was done by using Agar plate method Potato Dextrose Agar (PDA) as described by ISTA [20]. Seeds were treated with surface sterilization by soacking them in $1 \%$ sodium hypochlorite $(\mathrm{NaOCl})$ for two minutes and finally washing in distilled water three times. Seeds were then incubated for 7 to 14 days at $25^{\circ} \mathrm{C}$ and with alternating light and dark period of 12 hours. Forty seeds from each of the 30 seed samples of farmers $(9,12$ and 9 samples from Tullo, Doba and Gemechis districts, respectively) were used. At the end of incubation period, each seed was thoroughly examined under different magnification of compound and stereo-microscopes for fungal or bacterial contamination. Identification was made using morphological characteristics of the pathogens (colony characteristics, conidiophores, shape and septation of conidia and other structures) and comparison with appropriate literature. Percentage of infected seeds by total fungi and bacteria and by individual species was recorded.

\section{Data analysis}

The analysis of variance (ANOVA) for the parameters related to physical purity, physiological quality, and seed health test were analyzed using the Statistical Analysis System computer software (SAS Version 9.0). Treatment means were separated using Least Significance Difference (LSD) test. Percent data on physical and physiological test parameters were transformed using arcsine transformation method as described by Gomez and Gomez [25]. The mean percentage of quality parameters were computed and used for comparison of seed sources as well as sole and intercrop cropping systems.

\section{RESULTS}

\section{Physical purity}

Differences among the districts and between the two cropping systems were significant for percentage of pure seeds. The proportions of pure seed for samples collected from intercrop (98.2\%) and sole crop (98.9\%) were in the highest range of the purity standard of common bean seed in Ethiopia (Table 1,3). Similarly, pure seed percentages over districts ranged from 98.1 (Tullo) to 99.1 (Doba), which were also above common bean seed purity standard of the country (Table 1). According to the national common bean seed standard, the percentage of pure seed, inert matter and other crop seeds should be $95,2 \%$ and $0.7 \%$, respectively.

\section{Moisture content}

Differences in seed moisture content were significant among the districts but not between the two cropping systems. The average moisture content for sole and intercrop grown seeds were 11.9 and $11.5 \%$, respectively (Table 1). Average moisture content of seeds collected from different districts ranged from 11.4 (Tullo) to $12.4 \%$ 


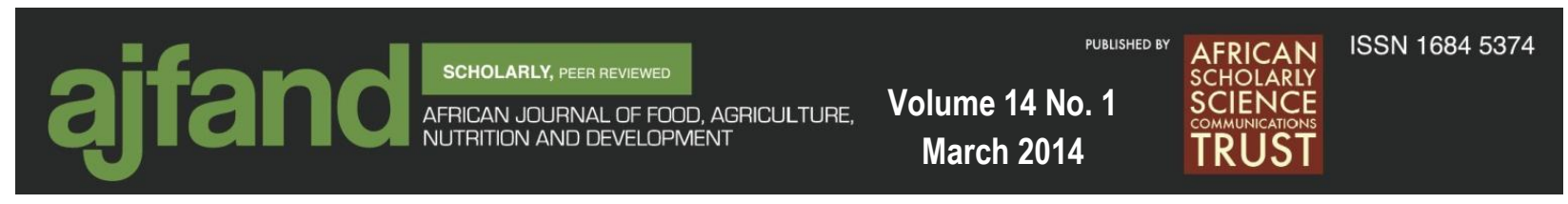

(Gemechis). Except for the samples from Gemechis, the seed moisture contents from the two districts met the seed moisture standard of common bean in Ethiopia (Table $1,3)$.

\section{Germination percentage}

Standard germination of seeds varied across the districts but not between the cropping systems. Seeds produced under intercrops exhibited relatively better normal germination (81.7\%) than those obtained from intercrops with other crops $(80.6 \%)$ (Table 2). However, germination percentage of seeds produced under both cropping systems did not fulfil the national standard set $(85 \%)$ for common bean seed in Ethiopia (Table 3). When germination percentages of seed samples collected from intercrop systems in the different districts were considered, those from Gemechis $(93.5 \%)$ and Tullo $(87.8 \%)$ fulfilled the national seed standard whereas those from Doba $(61.9 \%)$ did not (Table 2). For seeds produced under sole crop system, the highest $(93.5 \%)$ and the lowest $(60.6 \%)$ normal germination was found for those samples obtained from Gemechis and Tullo districts, respectively. Compared to other quality parameters, the range of standard germination of farmers' seeds produced under sole crop and intercrop was fairly wide (Table 3 ).

\section{Speed of germination}

Speed of germination of the seed samples was significantly different among the districts but not between the two cropping systems. Seed samples collected from Gemechis district had significanty low speed of germination compared with those obtained from Doba and Tullo (Fig. 2).
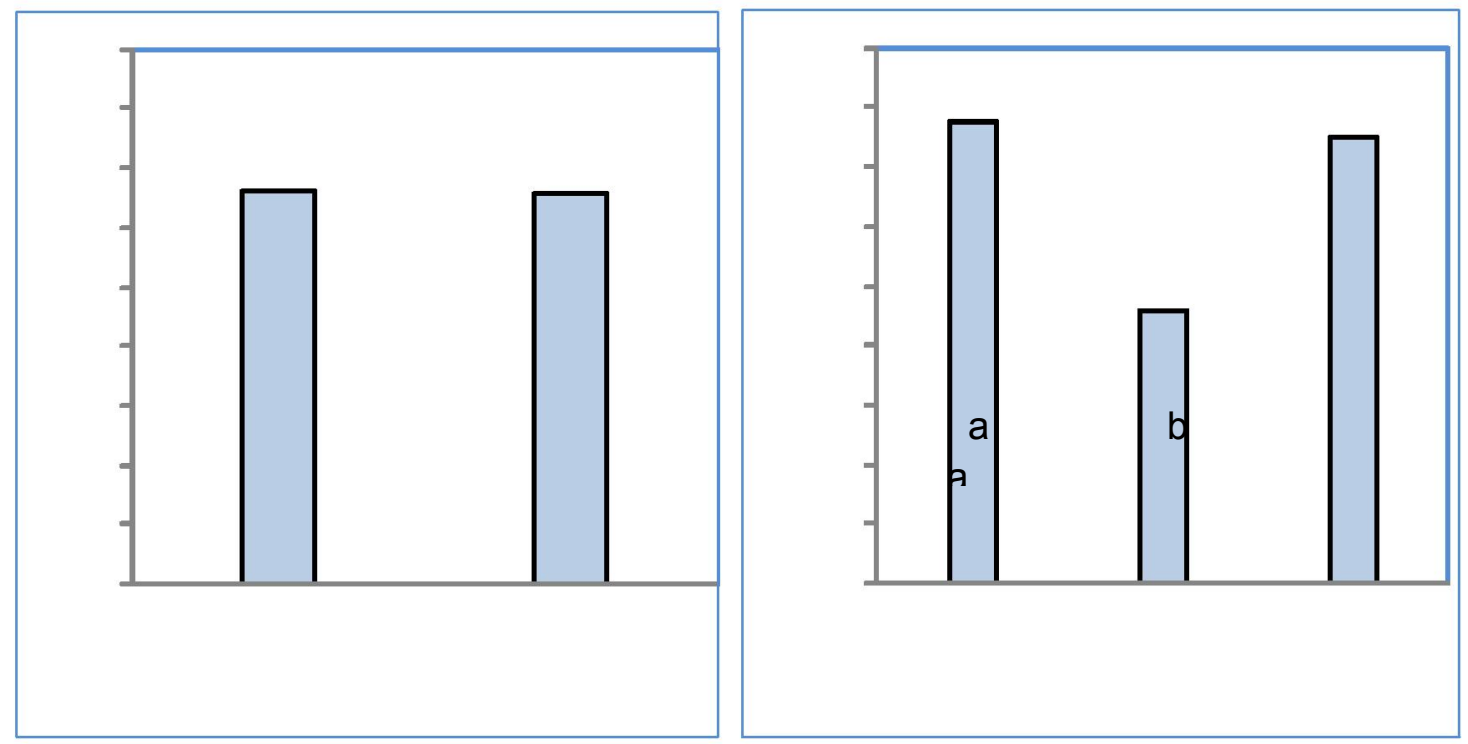

Figure 2: Speed of germination (days) of common bean seed samples produced under two cropping systems and collected from three districts of west Hararghe zone of Oromia region, eastern Ethiopia. 


\section{Length and weight of seedling shoot and root}

Average seedling shoot length of samples among the districts was found to be significantly different whereas such difference was not observed between the two cropping systems. Shoot length of seeds produced under sole $(23.0 \mathrm{~cm})$ and intercrop $(22.5 \mathrm{~cm})$ systems were comparable (Table 4). Considering the origin of seed samples, average shoot length of seeds was the highest for those from Tullo $(24.3 \mathrm{~cm})$ and the lowest $(20.2 \mathrm{~cm}$ ) for those from Gemechis (Table 4). Seedling root length was not significantly affected by both cropping system and districts from where seeds were obtained (Table 4). Seed samples produced under sole crop cropping systems had relatively longer average root length $(17.5 \mathrm{~cm})$ than those produced under intercrop system $(17.0 \mathrm{~cm})$ (Table 4). Seedling dry weight of seeds produced under sole crop $(0.78 \mathrm{~g})$ was relatively heavier than that produced under intercrop system (0.76 g) (Table 4).

\section{Vigor indices}

Both VGI-I and VGI-II did not differ between the seeds produced under the two cropping systems. However, significant differences were observed for both VGI-I and VGI-II between the districts where the seeds were collected. Significantly lower values of VGI-I and VGI-II was obtained from seed samples collected from Gemechis district than those seeds obtained from Doba and Tulo districts which had the same vigor indices (Table 4).

\section{Seed health test}

Seed born fungi pathogens detected on Agar plate of common bean seeds were Chaetomium, Phoma, Alternaria, Aspergillus, Fusarium, Rhizopus, Penicillium, Aspergillus flavus, Aspergillus niger, Aspergillus ochraceus, Aspergillus parasitica, Rhizoctonia bataticola and Rhizoctonia solani (Table 5). Common bacterial blight (CBB) caused by Xanthomonas campestris pv. phaseoli or Xanthomonas axonopodis cv phaseoli was the only bacterial disease found associated with bean seed samples. There was significant difference among cropping systems in percentage of infected seed samples obtained from smallholder farmers. Among the identified fungi species, Rhizopus was detected in 62.5 and $72.7 \%$ of seed samples obtained from sole crop and intercropping systems, respectively (Table 5). The average proportion of seed samples associated with seed born pathogens were $28.6 \%$ (with a range of 12.5 to $75.0 \%$ ) for sole crop and $27.3 \%$ (with a range of $0.0 \%$ to $72.7 \%$ ) for seeds produced under intercrop conditions (Table 5).

\section{DISCUSSION}

Relative to other seed quality parameters considered, farmers common bean seed quality obtained from both cropping systems were high and comparable to those of formal seed sector. Similar high (98.9\%) mean physical purity of farmers' wheat seed samples collected from different parts of Ethiopia were found for the majority of samples $(93 \% ; n=303)$ meeting the minimum purity standards for certified seed [26]. Both findings suggested that there is a widespread and well established skill and 


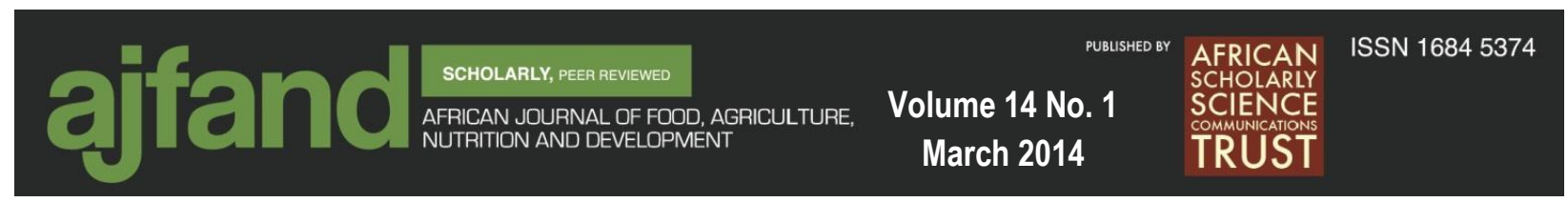

practices of maintaining the physical purity of seeds by smallholder farmers in Ethiopia.

Changes in seed moisture content of common bean seed stored for a period of three to six months was found to be the function of storage type (air tightness of the containers and subsequent contact of seeds with ambient room air) [27]. The same study report further noted that germination capacity of the seeds stored in containers such as tin pot which keep lower seed moisture content relative to the original were better than those stored in poly and jute bags commonly used as storage materials among bean growers of eastern Ethiopia. Relative to the national standard, mean germination percentage for seeds of both cropping systems were low although differences among the districts were considerable. Poor seed germination could result from poor preharvest seed management practices and post-harvest handling during processing, and particularly during storage condition. It was also reported that germination of wheat seed samples from farmers (with a few exceptions) met the minimum standards for certified wheat seed production in the country [28].

In agreement with findings of the current work, a study on groundnut revealed that root length, shoot length, seedling dry weight, and seedling vigour indices differed significantly among varied groundnut varieties and seed sources [29]. The same study revealed that good seed quality parameters such as speed of germination, shoot length and root length, seedling dry weight and vigour index might be probably due to abundant availability of moisture, nutrition during crop growth and low temperature during harvesting and drying period in ground nut. The difference in physiological quality of common bean seed of different sources may be attributed to differences in storage age and temperatures, seed moisture content in storage as well growers' level of awareness on seed production and handling [30]. A study has demonstrated that poor sorghum yield among $29 \%$ of sorghum growers in Bomet district of Kenya was accounted for by the poor physiological quality of the seed used as planting material [31].

Among the intercrop and sole crop seed samples, 59.1 and $75.0 \%$, respectively were associated with Common Bacterial Blight (CBB). Seed borne X. phaseoli is also common in both retained and certified common bean seed lots in other bean growing areas with the former having significantly higher bacterial population levels [32]. Thus, farmers are advised not to retain seeds over long periods as this may result in pathogen build-up. The proportion of seeds infected with the disease were less for those produced under intercrop conditions corroborating previous reports on reduced incidence of $\mathrm{CBB}$ for intercropped beans compared to sole crop in Hararghe highlands of Ethiopia [33]. The high percentage of incidence of the bacteria in a given location is known to cause serious challenge to seedling establishment, survival and yield of the crop.

Higher incidence and association with common bean seed samples of fungal and bacterial species agree with results of recent studies on common bean and other grain crops. For example, a study conducted on common bean seed quality of different 
formal and informal sources from the Central Rift Valley of Ethiopia indicated that Fusarium oxysporium and Aspergillus spp. were the two most common fungal diseases associated with seeds retained by farmers (own saved seeds) and those sampled from markets and cooperative unions [30]. Different Fusarium spp. and several saprophytic fungi such as Alternaria spp., Aspergillus spp., Cladosporium spp., Curvularia spp., Mucor spp., Nigrospora spp., Penicillium spp. and Trichothecium spp. have also been isolated from seed samples of other crops collected from farmers across different regions of Ethiopia [34].

\section{CONCLUSION}

Physical, physiological and health qualities of common bean seeds produced under sole and intercrop cropping systems in three districts of eastern Ethiopia were not significantly different. Lack of significant differences between the sole and intercrop systems in many of the seed quality parameters and their comparison with the required seed standards of the country indicated that good quality common bean seeds could be produced by farmers under both cropping systems. However, the significant differences among the districts in seed quality parameters and high number of seed born fugal and bacterial pathogens identified in this study suggest the need to improve pre and post-harvest crop management practices of farmers in those districts where seed quality parameters are low through farmer-to-farmer knowledge exchange and technical backstopping by research and extension services. 
Table 1: Proportion of pure seed and moisture content of common bean seed samples obtained from sole and intercropping systems from three districts of West Hararghe zone, eastern Ethiopia

\begin{tabular}{lll}
\hline \multirow{2}{*}{ Location / } & \multicolumn{2}{c}{ Parameters } \\
\cline { 2 - 3 } cropping system & Physical & Moisture \\
& purity (\%) & content (\%) \\
\hline Districts & & \\
\hline Doba & $99.09 \mathrm{a}$ & $11.51 \mathrm{~b}$ \\
Gemechis & $98.61 \mathrm{a}$ & $12.36 \mathrm{a}$ \\
Tulo & $98.09 \mathrm{~b}$ & $11.40 \mathrm{~b}$ \\
\hline LSD (0.05) & 0.51 & 0.56 \\
\hline
\end{tabular}

Cropping system

\begin{tabular}{lll}
\hline IC & $98.24 \mathrm{~b}$ & 11.56 \\
$\mathrm{SC}$ & $98.95 \mathrm{a}$ & 11.95 \\
\hline $\operatorname{LSD}(0.05)$ & 0.42 & $\mathrm{~ns}$
\end{tabular}

$\mathrm{IC}=$ intercrop; $\mathrm{SC}=$ sole crop; LSD $=$ least significant difference $;$ ns = non-significant

Means followed by same letter within the same row are not significantly different at $5 \%$ level of probability, according to lsd test. 
Table 2: Standard germination percentage and other physical purity characteristics of common bean seed samples obtained from sole and intercropping systems of smallholder farmers in three districts of West Hararghe zone, eastern Ethiopia

\begin{tabular}{|c|c|c|c|c|c|}
\hline \multirow[b]{2}{*}{ Cropping system } & \multirow[b]{2}{*}{ District } & \multicolumn{4}{|c|}{ Parameters } \\
\hline & & $\mathrm{SG}$ & TSW & OCS & WS \\
\hline \multirow{3}{*}{ Intercrop } & Doba & $90.7 \mathrm{ab}$ & $163.8 \mathrm{c}$ & $0.17 \mathrm{ab}$ & $0.002 b$ \\
\hline & Gemechis & $92.5 \mathrm{a}$ & $151.9 \mathrm{e}$ & $0.08 \mathrm{c}$ & $0.014 b$ \\
\hline & Tulo & $60.6 c$ & $174.4 \mathrm{a}$ & $0.23 \mathrm{a}$ & $0.00 \mathrm{~b}$ \\
\hline \multirow{3}{*}{ Sole crop } & Doba & $62.0 \mathrm{c}$ & $170.2 b$ & $0.13 b c$ & $0.042 \mathrm{a}$ \\
\hline & Gemechis & $93.5 \mathrm{a}$ & $161.6 \mathrm{~d}$ & $0.19 \mathrm{ab}$ & $0.00 \mathrm{~b}$ \\
\hline & Tulo & $87.8 \mathrm{~b}$ & $150.2 f$ & $0.14 b c$ & $0.00 \mathrm{~b}$ \\
\hline Mean & & 81.2 & 162.03 & 0.16 & 0.01 \\
\hline $\mathrm{CV}(\%)$ & & 2.64 & 0.45 & 22.91 & 83.78 \\
\hline $\operatorname{LSD}(0.05)$ & & 3.18 & 1.08 & 0.09 & 0.02 \\
\hline
\end{tabular}

$\mathrm{CV}=$ coefficient of variation, $\mathrm{SG}=$ standard germination, $\mathrm{OCS}=$ other crop seeds; $\mathrm{WS}$ = weed seeds, $\mathrm{TSW}=$ thousand seed weight. Means followed by same letter within the same row are not significantly different at $5 \%$ level of probability, according to lsd test. 
Table 3: Number of seed samples produced under sole and intercrop systems meeting the minimum Ethiopian national seed standards for certified and emergency seed

Samples Samples

Cropping No.

meeting min below min

Parameter

system samples Mean Range standards standard

\begin{tabular}{lcccccc}
\hline Standard germination & IC & 76 & 84.4 & $7.3-98.0$ & 61 & 15 \\
$(\mathrm{C} 1-\mathrm{C} 4$ \& E $>85 \%)$ & SC & 24 & 75.2 & $5.3-96.0$ & 12 & 12 \\
Physical purity & IC & 76 & 98.4 & $92.5-99.9$ & 76 & - \\
$(\mathrm{C} 1-\mathrm{C} 4 \& \mathrm{E} \geq 93 \%)$ & SC & 24 & 98.9 & $96.5-99.9$ & 24 & - \\
Moisture content & IC & 76 & 11.3 & $9.0-13.5$ & 61 & 15 \\
$(\mathrm{C} 1-\mathrm{C} 4 \& \mathrm{E}<12 \%)$ & SC & 24 & 11.9 & $10.5-13.0$ & 12 & 12 \\
\hline
\end{tabular}

$\mathrm{IC}=$ intercrop; $\mathrm{SC}=$ sole crop; $\mathrm{C} 1-\mathrm{C} 4=$ certified seed grade 1 to $4 ; \mathrm{E}=$ emergency seed; $\min =$ minimum 
Table 4: Physiological qualities of common bean seed samples obtained from sole and intercropping systems of smallholder farmers in three districts of West Hararghe zone, eastern Ethiopia

\begin{tabular}{lllllc}
\hline \multirow{2}{*}{ Districts } & \multicolumn{5}{c}{ Parameters } \\
\cline { 2 - 6 } & SL(mm) & RL(mm) & SDW(g) & VI-I & VI-II \\
\hline Doba & $23.8 \mathrm{a}$ & 17.9 & 0.77 & $3819 \mathrm{a}$ & $69.8 \mathrm{a}$ \\
Gemechis & $20.2 \mathrm{~b}$ & 16.4 & 0.79 & $2501 \mathrm{~b}$ & $51.8 \mathrm{~b}$ \\
Tulo & $24.3 \mathrm{a}$ & 17.6 & 0.74 & $3784 \mathrm{a}$ & $66.5 \mathrm{a}$ \\
\hline LSD & 1.6 & $\mathrm{~ns}$ & $\mathrm{~ns}$ & 235 & 7.8 \\
\hline Cropping systems & & & & & \\
\hline IC & 22.5 & 17.0 & 0.76 & 3349 & 62.3 \\
SC & 23.0 & 17.5 & 0.78 & 3392 & 63.1 \\
\hline LSD & & & & & \\
\hline
\end{tabular}


Table 5: Mean percentage comparison of seed infection with microbes between bean seed samples obtained from sole and intercrop cropping systems of smallholder farmers in three districts of West Hararghe Zone, Eastern Ethiopia

\begin{tabular}{|c|c|c|c|}
\hline \multirow{2}{*}{$\begin{array}{l}\text { Bacterial / fungal species } \\
\text { detected }\end{array}$} & \multicolumn{3}{|c|}{ Proportion of seeds infected (\%) } \\
\hline & $\mathrm{SC}$ & $\mathrm{IC}$ & Both CSs \\
\hline CBB, Xanthomonas campestris & 75.0 & 59.1 & 67.1 \\
\hline Aspergillus & 25.0 & 50.0 & 37.5 \\
\hline Penicillium & 12.5 & 36.4 & 24.4 \\
\hline Alternaria & 12.5 & 9.1 & 10.8 \\
\hline Fusarium & 12.5 & 9.1 & 10.8 \\
\hline Chaetomium & 37.5 & 40.9 & 39.2 \\
\hline Phoma & 25.0 & 0.0 & 12.5 \\
\hline Rhiyzopus & 62.5 & 72.7 & 67.6 \\
\hline Aspergilus ocraceous & 12.5 & 22.7 & 17.6 \\
\hline Aspergillus flavus & 12.5 & 13.6 & 13.1 \\
\hline Aspergillus niger & 25.0 & 4.6 & 14.8 \\
\hline Aspergillus parasitica & 12.5 & 13.6 & 13.1 \\
\hline Rhizoctonia bataticola & 37.5 & 22.7 & 30.1 \\
\hline Rhizoctonia solani & 37.5 & 9.1 & 23.3 \\
\hline Mean & 28.6 & 26.0 & 27.3 \\
\hline
\end{tabular}




\section{REFERENCES}

1. Habtu A Epidemiology of bean rust in Ethiopia, $\mathrm{PhD}$ Thesis. The Netherlands: Wageningen Agricultural University 1994; 172pp.

2. CSA (Central Statistics Agency of Ethiopia) Report on area and crop production forecast for major crops for 2012/13 Meher season, Statistical Bulletin 2012; 128 pp.

3. Habtu A, Sache I and JC Zadoks A survey of cropping practices and foliar diseases of common bean in Ethiopia. Crop Protection, 1996; 15: 179 - 186.

4. Fininsa $\mathbf{C}$ and $\mathbf{J}$ Yuen Association of bean rust and common bacterial blight epidemics with cropping systems in Hararghe highlands, eastern Ethiopia. Int. J. Pest Man, 2001; 47: $211-219$.

5. Eden T Uptake and Response of Haricot Bean (Phaseolus vulgaris L.) Varieties to Different Levels of Phosphorus Application on Entisols of Alemaya. M.Sc. Thesis. Alemaya University, Alemaya 2002; 90pp.

6. Fininsa C Epidemiology of Bean Bacterial Blight and Maize Rust in Intercropping, Doctoral Thesis, Swedish University of Agricultural Science, Uppsala 2001.

7. Belay S, Wortmann CWS and G Hoogenboom Haricot bean agro ecology in Ethiopia: definition using agro climatic and crop growth simulation models. African Crop Science Journal, 1998; 6: 9 - 18.

8. Tamado T and M Eshetu Evaluation of sorghum, maize and common bean intercropping systems in eastern Ethiopia. Ethiopian Journal of Agricultural Science, 2000; 17: 33 - 46.

9. Fininsa $\mathbf{C}$ Effect of planting pattern, relative planting date and intra-row spacing on a haricot bean/maize intercrop. African Crop Science Journal, 1997; 5: $15-22$.

10. Kedir O Assessment of seed quality of common bean (Phaseolus vulgaris L), produced under different cropping systems in western hararghe zone, ethiopia MSc Thesis, Haramaya University 2012: 99pp.

11. Katungi E, Farrow A, Chianu J, Sperling $\mathbf{L}$ and $\mathbf{S}$ Beebe Common bean in Eastern and Southern Africa: a situation and outlook analysis, ICRISAT 2009.

12. Nangju D, Wien HC and B Ndimande Improved practice of soybean seed production in the tropics. In Seed Production. (Ed.Hebblethwaite PO). London Butterworth 1980: 427 - 448. 
13. Delouche JC Physiological changes during storage that affects soybean seed quality. Soybean seed quality and stand establishment. INTSOY Series, 1980; 22: 12-19.

14. Sinclair JB Some important seed- and soil-borne bacterial and fungal pathogens of soybeans. Proceedings of a Conference for Scientists of Africa, Middle East and South Asia October 14-17, 1974. Addis Ababa, Ethiopia 1974: $124-131$.

15. Martins RA, Smith OS and M O'Neil Relationships between laboratory tests and field emergence of maize inbreds. Crop Sci. 1988; 28: 801- 805.

16. Cervantes CN Productivity and seed quality of maize (Zea mays L.) and peanut (Arachis hypogaea L.) grown as monocrop and as intercrop in low and high external input systems, MSc Thesis, Philippines Univ. Los Banos, College 1997; 119pp.

17. Chavez VP and TC Mendoza Seed quality of three field legumes as affected by sugarcane intercropping, Philippine Journal of Crop Science, 1986; 11(1): $61-66$.

18. Ogutu MO, Owuoche JO, Muasya R and G Ouma Effects of inter-specific interaction of nitrogen fertilizer and bean-maize cropping systems on quality of bean seed in Western Kenya, Agric. Biol. J. N. Am., 2012; 3(4): 154 - 168.

19. Fairey DT and JG Hampton Forage seed production. London, UK 1998: 286 - 304.

20. ISTA (International Seed Testing Association) International Rule for Seed Testing, Seed Science and Technology, 1993; 21: $1-288$.

21. ISTA (International Seed Testing Association) International Rules for Seed Testing. Seed Science and Technology, 1985; 13: $322-343$.

22. ISTA (International Seed Testing Association) International Rule for Seed Testing, Seed Science and Technology, 21(Suppl.): 1B288, Zurich, Switzerland 1996.

23. Khare JW and RD Bhale Seed Science and Technology. Oxford and IBH Publishing Co. New Delhi, Bombay 2005: 112 - 114.

24. Maguire JD Speed of germination, an aid in selection and evaluation for seedling emergence and vigor. Crop Sci., 1962; 2: 176 - 177.

25. Gomez KA and AA Gomez Statistical procedures for agricultural research. Second edition. International Rice Research Institute. John Wile and Sons Inc. 1984: 304 - 308 . 
26. Bishaw Z, Struikb PC and AJG Van Gastelac Farmers seed sources and seed quality: Physical and physiological quality, Journal of Crop Improvement, 2012; 26(5): 655 - 692 .

27. Nahar K, Ali MH, Ruhul Amin AKM and M Hasanuzzaman Moisture Content and Germination of Bean (Phaseolus vulgaris L.) Under Different Storage Conditions, Academic Journal of Plant Sciences, 2009; 2(4): 237241.

28. Alemayehu Z, Ensermu R, Yaie B, Girma B, Taye G and M Hassena Farmers' feedback on the status of released bread wheat varieties in Chilalo awaraja, Arsi Zone, Ethiopia. pp. 106-113. In: Tenth Regional Wheat Workshop for Eastern, Central and Southern Africa, 14-18 Sep 1998, University of Stellenbosch, South Africa. CIMMYT, Addis Ababa, Ethiopia 1999.

29. Mahesh CG Effect of seed source, growing season and genotypes on seed yield and quality in Groundnut (Arachis hypogaea L.) in Dharwad. MSc. Thesis, University of Agricultural Sciences, Dharwad 2007; 80pp.

30. Wakessa T Assessment of common bean (phaseolus vulgaris 1.) seed quality of different seed sources in central rift valley, Ethiopia, MSc Thesis, Haramaya University 2010; 84pp.

31. Ochieng LA, Mathenge $\mathbf{P W}$ and $\mathbf{R}$ Muasya An assessment of the physiological quality of sorghum (Sorghum bicolor L moench) seeds planted by farmers in Bomet district of Kenya, African Journal of Food, Agriculture and Nutrition Development, 2012; 12(5): 6385 - 6396.

32. Karavina $\mathbf{C}$, Chihiya $\mathbf{J}$ and TA Tigere Detection and characterization of Xanthomonas phaseoli (e. f. sm) in common bean (Phaseolus vulgaris L) seeds collected in Zimbabwe. Journal of Sustainable Development in Africa, 2008; 10 (1): $105-119$.

33. Fininsa C Relationship between common bacterial blight severity and bean yield loss in pure stand and bean - maize intercropping systems. Int. J. Pest Man, 2003, 49(3): 177-185.

34. Bishaw Z, Sahilu Y and B Simane The status of the Ethiopian seed industry: In: M. H. Thijssen, Zewdie Bishaw, Abdurahman Beshir, and W. S. de Boef, Farmers seed and varieties: Supporting informal seed supply in Ethiopia (eds.). 23 - 32. Wageningen, the Netherlands, Wageningen International 2008. 